\title{
ENVIRONMENTAL POLICIES AND SOCIO-TERRITORIAL IMPACT IN LACANDON JUNGLE 2002-2012
}

\author{
S. E. VALLE-GARCÍA \\ Universidad Nacional Autónoma de México, México
}

\begin{abstract}
In México, since the beginning of the 21st century, the government has established a scheme of environmental policies in socially poor and environmentally rich areas like the Lacandon Jungle. The policies concern Protected Natural Areas (PNAs), Payments for Ecosystem Services (PESs) and sustainable activities such as ecotourism. In order to understand the socio-territorial impact, a comparative analysis was made of three communities with different governmental initiatives, using ethnographic methods - life stories, in-depth interviews and participant observations - and cartography methods with remote sensing analysis of spot images. The results show that, when the level of cash transfers is high, the subsidies cause the beneficiaries to be more dependent on the government for their livelihoods; the restricted areas have led to changes in the landscape, causing high rates of deforestation in small areas and finally, well-being is also directly correlated with social capital. However, at the same time, there is a high level of social polarization.

Keywords: environmental policies, policies' impacts and socio-territorial changes.
\end{abstract}

\section{INTRODUCTION}

Since the last part of the 19th century, environmental policies and their socio-territorial impacts have gained relevance in the area of conservation [1].

Land cover, land use and landscape are the main concepts that feature in socio-spatial change [2]. The transition of land cover shows the landscape change. These changes are linked to heterogeneous socio-economic situations and the interaction between global markets, national politics and local stakeholders. In this sense, the policies' effectiveness and their impact on the territory are associated with political willingness; nevertheless, it is an oversimplification to attribute every aspect of the process of degradation or conservation to policies [3-5]. For example, when an environmental policy is good, it is possible to observe the correlation between behaviour change and positive effect across the territory [6]. Also, when there is a regional/national landscape change, it is possible to discover general patterns although not homogeneous - in local specific changes. This spatial analysis facilitates a discussion on the new alternatives for favourable policies in regions involved in a critical process of change [7].

In Mexico, the preservation of nature through environmental policies has been facilitated by the establishment of Protected Natural Areas (PNAs), the scheme of Conditional Cash Transfers (CCT), such as Payments for Ecosystem Services (PES), and the promotion of sustainable economic activities, such as ecotourism [1,8-11].

In this context, the Lacandon Jungle in Chiapas-Mexico is a highly studied area. Multiple researches have been undertaken on this subject; some examples are, mechanism of carbon 
50 Environmental and Economic Impact on Sustainable Development

fluxes for conservation, land use and land cover analysis [12]; traditional biodiversity uses for nature conservation $[13,14]$; deforestation process through time [15, 16]; economic and cultural characteristics [17]; socio-political organization and struggles [18]; rural development and regional studies [19]; livelihoods [20] and environmental policies' implementation and evaluation [21-23]. The environmental policies and its socio-territorial impacts.

Of particular importance is the socio-territorial impact caused by environmental policies and the recognition of whether the changes, which have occurred in the area, are attributable to environmental policies, and, if yes, why. For this reason, this paper's goal is to understand the environmental policies' socio-territorial impacts by means of a temporal and spatial comparative analysis, employing mixed methods of ethnography and cartography. The study area comprises three communities in the Lacandon Jungle, each with different governmental initiatives: San José, Plan de Ayutla and Lacanjá Chansayab. The period of analysis is from 2002 to 2012, a period of wide-reaching governmental action on environmental policies in the area.

The paper consists of three sections: history, objectives, mechanisms and scheme of implementation and the relevant actors in environmental policies in Mexico; the specific methodological procedures and the results regarding general patterns of the impact of environmental policies, the specific influence over the communities and the main socio-territorial impact of the environmental policies.

\section{MEXICAN ENVIRONMENTAL POLICIES: HISTORY, OBJECTIVES, IMPLEMENTATION AND ACTORS}

In order to understand the policies' impacts, it is necessary to know the reasons behind the design and implementation of the policies and to understand the population and targeted territories.

Because of this, the paper will describe the socio-spatial configuration of the study area in the Lacandon Jungle of Chiapas-Mexico from the agrarian and ecological policies of the 1970s, followed by the political struggles of the 1990s and the deployment of low-intensity warfare between the government and the Zapatist indigenous people that would fragment the Lacandon Jungle territory in 2000.

In the same way, it will relate the influence of environmental policies on the targeted population's behaviour and their territory. It will also describe the objectives and mechanisms in the implementation of the environmental programmes (actions and actors) to understand the nodal labels of the environmental policies.

\subsection{Historic context of the implementation of the environmental policies in the Lacandon Jungle}

The Lacandon Jungle is the largest ecological reserve, with a Perenial, coniferous and mesophile rainforest ecosystem [24], and the most culturally diverse area of Chiapas-Mexico $[23,25]$.

Two main policies have defined the region: first, the agrarian declaration in 1972, which assigned to 66 Lacandon households 614321 ha in three settlements: Naha, Metzabok and Lacanjá Chansayab in order to define the Lacandon Community Zone (CZL in Spanish) [24], and, second, the ecological declaration in 1978 with the creation of the PNA of Reserve Biosphere Montes Azules (REBiMA in Spanish) of 331200 ha [24], a polygon that overlaps CZL. 
Later, in 1994, the social movement of the Zapatist Army of National Liberation (EZLN in Spanish) emerged, with the goals of freedom and autonomy for the indigenous communities. In 1998 the struggle sharpens, and politics played an important role in the forced fragmentation of the region, into the privileged Lacandon group in the east and the settlement of the marginalized group in Cañadas in the west (Tzotziles, Tzeltales and Tojolabales).

Finally, in 2000, low-intensity warfare began with an increasing number of environmental programmes in different places. The objective was to pressurise the communities involved in political resistance to leave their movements, accept the policies, avoid eviction and dispossession of the tenure of their land and gain subsidies that guaranteed their livelihoods.

\subsection{Environmental policies: objectives and implementation}

The multilateral strategies for nature preservation and poverty alleviation are: subsidies for consumption in Payments for Ecosystem Services (PES), sustainable economic activities like ecotourism and the restriction of land use with the establishment of the Protected Natural Areas (PNAs).

The PES is also a climate change mitigation programme for reducing deforestation with an economic valuation of the ecosystem services [9] involving a Conditional Cash Transfer (CCT) to peasants in order to reduce the impact of climate variability and contribute to agriculture welfare [11]. Nevertheless, there is ambiguity surrounding PES because the beneficiaries are farmers with land tenure, who, further, are in the top stratum above the rest, namely, the landless farmers. In short, it is a subsidy targeted at the poor rural-rich and not the poor rural-poor, marginalizing the poorest [9-11].

Regarding natural resources in the scheme, in sustainable economic activities underlie the dilemma of agriculture, like the threat to environmental preservation and no like the livelihood options of food supply [26, 27]. For this reason, it promotes an alternative activity with indirect landscape use and seasonal, temporary and diversified income for people of rural areas: ecotourism [11]. However, this is an activity that undervalues the ancestral wisdom of peasants [10], cancelling their land property rights - territory and natural resources; it is an activity with highly negative impacts on the environment, and one which does not promote economic diversification [1]. In consequence, the transition of economic activity - from primary to tertiary - has promoted vulnerability of livelihoods in rural communities.

The PNAs are developed with external technical assistance, alongside the participation of the communities. But, this is a conservation strategy that restricts the use and possession of space for farmers' livelihoods [11]. Hence, it results in the phenomenon of displacement of the poor/indigenous/peasant people [1].

In sum, the environmental policies associated with PES, PNAs and ecotourism do not consider other causes of deforestation, which are not local activities carried out for livelihoods. In addition, it is an exclusive model regarding habitability, it infringes on human rights in respect of customs, land tenure and territory, and it also promotes unequal contracts between local communities and the government or market $[8,1]$.

\subsubsection{The Mexican case}

In Mexico, the mechanisms of the implementations of policies are: CCT for health, food, education, farming and touristic activities, biodiversity and ecosystem preservation/restoration; public services, infrastructure and sanitation in local communities; training and technical assistance for encouraging farmers and those employed in tourism into sustainable activities; 
52 Environmental and Economic Impact on Sustainable Development

and consolidation of sustainable production projects. The governmental institution responsible for environmental issues is the Secretary of Environmental and Natural Resources (SEMARNAT in Spanish). Through the National Commission of Protected Natural Areas (CONANP in Spanish) and the Forest National Commission (CONAFOR in Spanish), it promotes [28-30]:

Programmes for conservation and sustainable development (PRCODES in Spanish) by the implementation of sustainable projects like ecotourism within PNAs in indigenous areas.

Forest National Programmes (PRONAFOR in Spanish) with payments for hydrological ecosystem services (PES-H) and payments for ecosystem services for carbon sequestration, biodiversity and agroforestry systems (PES-CSBAS), witheconomic valuation of changes in the behaviour of farmers with respect to the natural resources' management, with CCT.

The establishment of PNAs to restrict human activities in areas with low environmental disturbance or that need protection/restoration.

These programmes consolidate a scheme for implementing environmental policies with clear and transversal objectives for nature preservation, sustainable livelihoods and human well-being; see Table1.

The implementation of environmental policies involves twointermediaries between the governmental institution and the local communities. First, each secretary has a workgroup called the "promoter's link", linking the programme, as written on paper, with the in-field reality; they have to go to communities in order to explain the programme's objectives, benefits and requirements. Second, in common use in rural areas, there is a general assembly that assigns different workgroups to meet the needs of the population in areas like health, education, agrarian issues and environmental interest; at the same time, if they are in contact with a governmental programme, they will be assigned a representative person to forge the link to connect the community, general assembly and government.

Table 1: Scheme of environmental policies in Mexico.

\begin{tabular}{llll}
\hline Programme & \multicolumn{1}{c}{ Objective } & \multicolumn{1}{c}{ Actions } & \multicolumn{1}{c}{ Labels } \\
\hline PROCODES & $\begin{array}{l}\text { Biodiversity and ecosystem } \\
\text { preservation, restoration and } \\
\text { sustainable use to improve } \\
\text { human well-being }\end{array}$ & $\begin{array}{l}\text { Local people's par- } \\
\text { ticipation in natural } \\
\text { resources' management } \\
\text { with alternative produc- } \\
\text { tive options }\end{array}$ & $\begin{array}{l}\text { Landscape } \\
\text { (preservation and } \\
\text { restoration of }\end{array}$ \\
nature)
\end{tabular}


When the explanation is very clear and of interest to the community, it is possible to come to an agreement on the implementation of the programme. Much depends on the clarity and political intention of the scheme and on local community cohesion.

\section{METHODOLOGY}

The socio-environmental analysis will approach the impact of environmental policies implemented in Mexico by means of a case study in Lacandon Jungle in the period 2002-2012. The methodological procedure will try to discover whether the changes to the territory are attributable to environmental policies and what is the impact of the environmental policies. For this reason, the stages are:

Comparative analysis between the three communities, with different levels of governmental attention, within the same region.

The scales of analysis are macro-spatial, with remote sensing in order to understand the change in land use, land cover and landscape over time; and micro-social, in order to understand the social dynamics, people's behaviour and life conditions that have changed in recent years.

The two previous stages seek a historic comprehension of general patterns in the region and the claim of contextual specificities.

\subsection{Lacandon Jungle: Tzeltal and Lacandon people}

The conceptual construct "Lacandon Jungle" has diverse historic, territorial, political, ideological and cultural meanings. On one hand, it means the cultural and ecological space of the "native people" of Lacandon ethnicity or "hach winik", who are the jungle's guardians. On the other hand, it is the space where the struggle was begun by those who live in the mountains for land, peace and social justice. Lastly, the jungle is the scientific laboratory for the preservation of the territory.

The first community is that of San José - Tzeltal ethnicity - who have settled in upland Cañada Taniperla. This community has resisted arduous and consecutive institutional intimidation and multiple attempts at dispossession. Another Tzeltal community is Plan de Ayutla, whose people did not give into pressure from the government to be relocated, even though their land was in the heart of the biosphere reserve, "Monte Azules" (REBIMA in Spanish). The third community is that of the Lacandon people, settled in lowland Lacanjá Chansayab, who affirm that they are the only ethnic people capable of living in harmony with nature and the government and refuse to acknowledge other indigenous people.

\subsection{Methodological strategy}

The labels used for measuring the impact of the environmental policies in the Lacandon Jungle, Chiapas-Mexico, were taken from the three sustainable conservation strategies, PES, PNAs and ecotourism, through the PRONAFOR, PNA and PROCODES programmes. They are:

a) Landscape: change in land use and land cover that modifies the landscape conditions

b) Livelihoods: change in land use for economic activities that impact livelihoods

c) Well-being: change in purchasing power, which is reflected in life conditions.

The methods used were ethnography, involving participant observation and in-depth interviews with older people and key actors' life histories that could describe changes in the 
community - the issues and the reasons for them - and cartography, which used GIS analysis (Geographic Information System) with satellite images spot 5 for Unsupervised Classification using Idrisi-Andes programme. Five land use topics were analysed: infrastructure, rainforest, cropland, pastureland and acahual (a Mexican concept to describe an area that was deforested and after five or ten years has recovered with secondary vegetation) in the period 2004-2013.

The data was collected from August 2014 to January 2015 during a stay of approximately two months in each community in order to experience the lifestyle of an average family, to participate in the activities involved in their livelihoods and to carry out walks all around the community in order to distinguish the land use territory patterns.

\section{RESULTS: THE ENVIRONMENTAL POLICIES' IMPACT: REAL OR NOT?}

The socio-environmental process of change are related with: the community history, internal socio-political dynamics and a relationship between government and community through policies for assimilation of the people.

The environmental policies in the territory have been developed through the promotion of productive activities, the aim to preserve nature and subsidies for well-being.

The point of departure for change in Lacandon Jungle was the livelihood transition economic activity and land use - followed by an abrupt shift in the landscape and the gradual modification in their life conditions into well-being for the better. The transition was made from silvicultural livelihood to agriculture and/or touristic service sector livelihood.

Conservation of the environment was a traditional activity in the communities of Lacandon Jungle, because the resources were used for livelihood - house building, fuel and food. For this reason, conservation behaviour is notmotivated by the government, but local deforestation for livelihood purposes is. That gives rise to other local environmental problems like climate variability, loss of biodiversity and soil erosion.

In the same way, the change in livelihood encourages the modification of purchasing power. This has changed the patterns of consumption and the people's diet, which has provoked, on one hand, an increase in solid waste and, on the other hand, chronic degenerative diseases.

\subsection{The socio-spatial change in Lacandon Jungle}

The relevance of research is to discover the general patterns of change, and at the same time to understand particular historical junctures. Likewise, the methodological challenge is to isolate data and discover whether the change produced is due to the environmental policy or not. Then, general findings about each of the three case studies can be presented.

\subsubsection{San José, Chiapas-Mexico}

San José community had not been the recipient of governmental programmes until 2002 and then only Oportunidades, a social programme, was introduced for 50 percent of the population. In 1994 the community participated in the army struggle of EZLN. The theft of livestock and land was an expression of the fight, resistance and social justice. The farming community became ranchers, causing abrupt changes in the landscape and livelihood but not in wellbeing. Nevertheless, rancher activities could not be sustained for long because the people did not have the abilities necessary for raising and selling livestock.

The landscape modifications between 2004 and 2013 were as follows (see Figure 1). In the image of 2004, intensive pastureland use and some areas of acahuales and cropland - corn and coffee - can still be seen. In 2013, the pastureland has decreased and shifted into aca- 

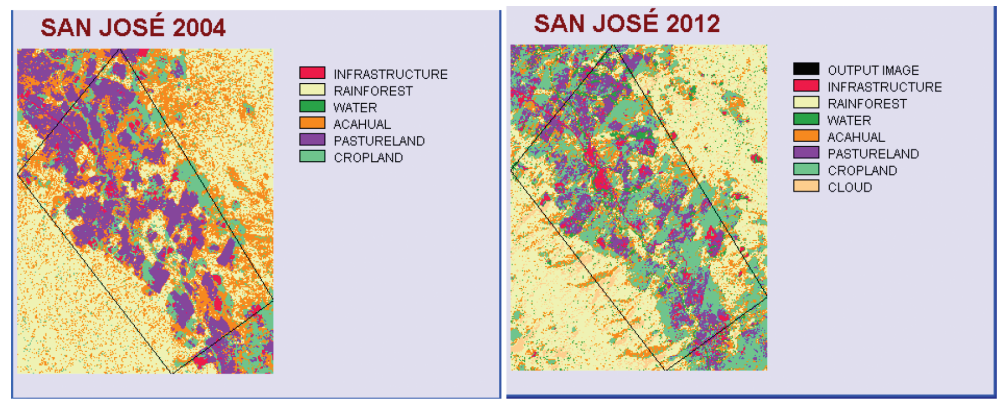

Figure 1. Land use in San José from 2004 to 2013

huales and cropland shows mainly corn. The rainforest has undergone a slight process of recovery - from acahuales to restored rainforest - and a slight decrease in cropland can be seen. There has also been too great an increase in infrastructure use due to the increasing population.

Last, the conditions for well-being have not shown remarkable improvement, in this sense; there is a negative connotation regarding governmental subsidies: "it is like selling your land and children for a small amount of money".

\subsubsection{Plan de Ayutla, Chiapas-Mexico}

In the community of Plan de Ayutla, environmental policies since 2004 have promoted a change in land use with regard to livelihood, preservation and life conditions. The promotion of economic activities in the form of raising cattle, in order to improve well-being, generated an abrupt landscape change with accelerated deforestation; livelihood diversification has been gradual and there has been a remarkable, although slow, improvement in living conditions.

Over the ten years, the land cover and acahual areas have decreased, while the cropland and pastureland have increased, apparently on a long-term trend. The change has improved living conditions, but this is not the case for environmental conditions.

\subsubsection{Lacanjá Chansayab, Chiapas-Mexico}

In the Lacanjá Chansayb community, the environmental policies since 1998 - action linked with other international aid - have generated changes in land use, nature preservation and life conditions, with the promotion of ecotourism activities. Because of this, it is a community that has abruptly changed in livelihood, well-being and landscape, with improvements in rainforest preservation and, in some cases, in life conditions. Nevertheless, this situation has also incited conflicts and inequality within the community. In addition, the tourism dynamics, as a seasonal activity, has had negative implications for incomes, because it is unstable, and the intermediaries - tourism agencies - are left with most of the financial resources.

In the period from 2004 to 2012, with the increase in ecotourism activities, remarkably, the restoration of land cover was mostly from acahual to reforested rainforest and from cropland to acahual use. In this sense, the Lacandon people shifted from direct to indirect use of the rainforest for their livelihood. Nevertheless, the traditional practices are lost, the short-scale cropland and rotative use for soil restoration are forgotten, and the agriculture is negatively stigmatized. It was assumed, in the government's position, that it would only be possible to 
56 Environmental and Economic Impact on Sustainable Development
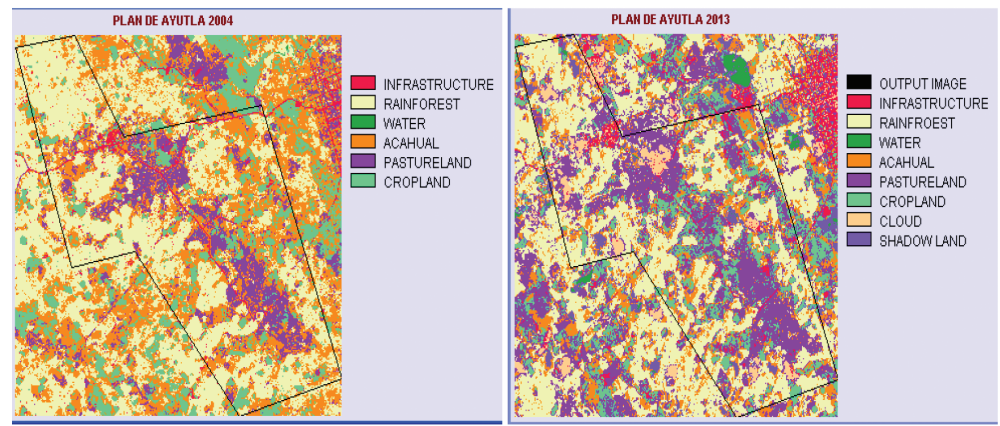

Figure 2. Land use change in Plan de Ayutla from 2004 to 2012.
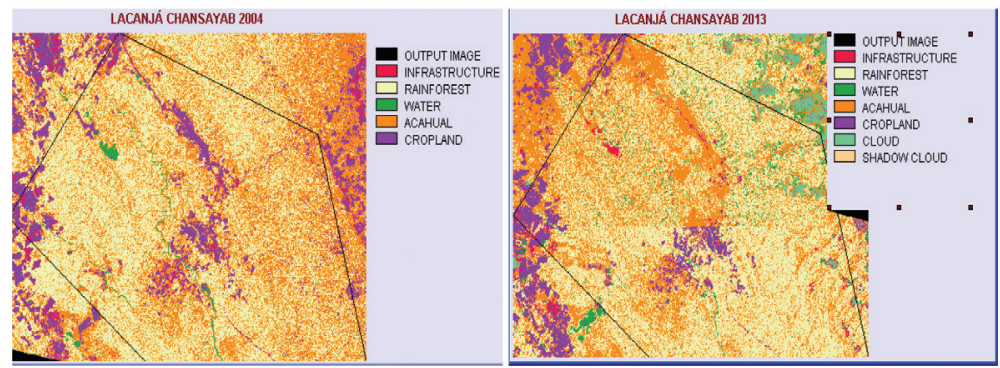

Figure 3. Land use change in Lacanjá Chansayab from 2004 to 2012.

eradicate poverty and preserve nature by introducing ecotourism service activities, regardless of the local and ancestral knowledge.

\subsection{The socio-territorial impact on Lacandon Jungle}

In sum, the socio-territorial impact of the environmental policies is, up to a certain point and taking into consideration the nuances in the relationship between the government and the local communities, on territorial autonomy, because the freedom for land use and land change is less dependent on the needs and concerns of the population than on governmental regulatory provisions.

Finally, the assimilation of governmental intervention with subsidies, infrastructure and public services, training in conservation and productivity activities, has had a major influence on life conditions, because if the economic resources are used with a long-term perspective this will result in improvement without the tie of dependence on the government.

\section{FINAL COMMENTS}

Environmental policies have an impact on the well-being of the people and environmental preservation through livelihood. However, the changes caused by the policies have resulted in either landscape change through deforestation/over-intensification of soil use in exchange for well-being, or simultaneously well-being with conservation of nature through sector service transition but with much conflict and high dependence on governmental subsidies.

The recurrent errors in governmental implementation are in homogenizing all environmental and social issues, and underestimating the local knowledge and abilities. For this reason, 
the most severe impact on the communities is their loss of autonomy over their territory and of their freedom with regard to the use of natural resources.

To better interpret governmental action throughout the territory, this paper used a methodological procedure to analyse the environmental impact on three different communities, by understanding the total impact through particular effects and recognizing the boundaries between the effects of policies and the expression of change intrinsic to the community.

The achievements were:

a) The micro-macro methodology of collecting data allows understanding of the changes in the livelihood, landscape and well-being.

b) Comparative analysis over a long of period time shows the contextual and historic elements of change.

c) Comparative analysis among the three different communities enables the expression of the impact of the real environmental policies.

Future challenges are:

a) To distinguish, in the mechanism of implementation, between the effects of the national macro-policy and the particular objectives of environmental policies.

b) To clearly distinguish the actions of different secretaries, stakeholders and multilateral organizations.

c) To further complex interaction between government and local communities in order to better understand the desire for change, the side effects of change and the changes that actually occur.

\section{REFERENCES}

[1] Roe, D., The origins and evolution of the conservation-poverty debate: a review of key literature, events and policy processes. Oryx, 42(4), pp. 491-503, 2008. http://dx.doi.org/10.1017/S0030605308002032

[2] Niemi, G.J., Johnson, L.B. \& Howe, R.W., Environmental indicators of land cover, land use, and landscape change, eds. R.H. Armon \& O. Hänninen, Environmental Indicators, Springer Science \& Business Media Dordrecht, pp. 265-276, 2015.

http://dx.doi.org/10.1007/978-94-017-9499-2_16

[3] Reid, R.S., Tomich, T.P., Xu, J., Geist, H., Mather, A., DeFries, R.S., Liu, J., Alves, D., Agbola, B., Lambin, E.F., Chabbra, A., Veldkamp, T., Kok, K., Noordwijk, M., Thomas, D., Palm, C. \& Verburg, P.H., Linking land-change science and policy: current lessons and future integration. In Land-Use and Land-Cover Change, eds. E.F. Lambin \& H. Geist, Springer: Berlin Heidelberg, 2006. http://dx.doi.org/10.1007/3-540-32202-7_7

[4] Pacheco, P., Aguilar-Støen, M., Börner, J., Etter, A., Putzel, L. \& Vera Diaz, M.D, Landscape transformation in tropical latin america: assessing trends and policy implications for REDD+. Forest, 2, pp. 1-29, 2011. http://dx.doi.org/10.3390/f2010001

[5] Aliste, E., Sustainability and territory: an approach to shape development from the perspective of the imaginary, ed. B. Werlen, Global Sustainability, pp. 119-135, 2015. 
58 Environmental and Economic Impact on Sustainable Development

[6] Chen, X., Lupi, F., He, G., Ouyang, Z. \& Liu, J., Factors affecting land reconversion plans following a payment for ecosystem service program. Biological Conservation, 142, pp. 1740-1747, 2009. http://dx.doi.org/10.1016/j.biocon.2009.03.012

[7] Dhakal, B., Bigsby, H. \& Cullen, R., Socioeconomic impacts of public forest policies on heterogeneous agricultural households. Environmental Resource Economics, 53, pp. 73-95, 2012. http://dx.doi.org/10.1007/s10640-012-9548-4

[8] Forsyth, T., Leanch, M. \& Scoones, I., Poverty and environment: priorities for research and policy. UNDP, European Comission, Institute of Development Studies, 1998.

[9] Hertel, T. \& Rosch, S., Climate change, agriculture and poverty. The World Bank, Agriculture and rural Development Team, 2010.

[10] Larson, D. \& Nash, J., Resource managemente and the effects of trade on vulnerable places and people: lessons from six case studies. The World Bank, Development Research Group. Agriculture and Rural Development Team, 2010.

[11] Vincent, J., Ecosystem services and greeen growth. The World Bank, Development Research Group, Environmental and Energy Team \& Sustainable Development Network, 2012.

[12] De Hong, B.H., Hellier, A., Castillo Santiago, M.A. \& Tipper, R., Application of the 'climafor' approach to estimate baseline carbon emissions of a forest conservation project in the selva lacandona, chiapas, Mexico. Mitigation and Adaptation Strategies for Global Change, 10, pp. 265-278, 2005.

http://dx.doi.org/10.1007/s11027-005-7132-8

[13] Tejeda Cruz, C., Conservacion de la Biodiversidad y Comunidades Locales: Conflictos en Áreas Naturales Protegidas de la Selva Lac Andona, Chiapas, México. Canadian Journal of Latin American and Caribbean Studies, 34(68), pp. 57-88, 2009. http://dx.doi.org/10.1080/08263663.2009.10816975

[14] Buda Arango, G., Trench, T. \& Durand, L., El aprovechamiento de palma camedor en la Selva Lacandona, Chiapas, México. ¿Conservación con desarrollo? Estudios Sociales, 22(44), pp. 199-223, 2014.

[15] O' Brien, K.L., Deforestation and climate change in the Selva Lacandona of Chiapas, Mexico: some preliminary results. Norwegian Journal of Geography, 49(3), pp. 105122, 1995.

[16] Gaona Ochoa, S., Hernández Vázquez, F., De Jong, B.H. \& Gurri García, F.D., Pérdida de diversidad florística ante un gradiente de intensificación del sistema agrícola de rozatumba-quema: un estudio de caso en la selva Lacandona, Chiapas, México. Ecología, 81, pp. 65-80, 2007.

[17] Trench, T., Representaciones y sus impactos: el caso de los lacandones en la Selva Lacandona. Liminar, 3(2), pp. 48-69, 2005.

[18] Van der Haar, G., El movimiento zapatista de Chiapas: dimensiones de su lucha, Labouragain Publications, pp. 1-24. 2005.

[19] Arreola, A., Peresgrovas, V., Reyes, C., Pérez, R. \& Martínez, R., De las metas a los procesos: la evaluación de proyectos de desarrollo rural exitosos en el área del Corredor Biológico Mesoamericano-Chiapas. Geografía Agrícola, 41, pp. 51-64, 2009.

[20] Tejeda Cruz, C. \& Marquéz Rosano, C., Los sistemas de producción en la selva lacandona. (el caso de Frontera Corozal, Chiapas). Ciencia y Tecnología en la Frontera, 1, pp. 19-30, 2004. 
[21] Mendéz Barrera, A., Planteamiento para la formulación de un programa de conservación y manejo regional para siete áreas naturales protegidas de la selva Lacandona, Chiapas, México, eds. G. Halffter, S. Guevara \& A. Melic, Hacia una cultura de conservación de la diversidad biológica, Zaragoza, España: Monografías tercer milenio, pp. 89-96,2007.

[22] Muñoz Piña, C., Rivera, M., Cisneros, A. \& García, H., Retos de la focalización del Programa de Pago por los Servicios Ambientales en México. Revista Española de Estudios Agrosociales y Pesqueros, 228, pp. 87-113, 2011.

[23] Pastor Alfonso, M.J., Gómez López, D. \& Espeso Molinero, M.D., Turismo comunitario y sus consecuencia entre los lacandones de Chiapas. Organismos y sistemas de apoyo. PASOS, pp. 23-43, 2012.

[24] Vos, J., Camino del Mayab. Cinco incursiones en el pasado de Chiapas, México: CEICH-UNAM, 2010.

[25] Boege, E., El patrimonio biocultural de los pueblos indígenas, México: Instituto Nacional de Antropología e Historia: Comisión Nacional para el Desarrollo de los Pueblos Indígenas, 2008.

[26] Timmer, P., Population, poverty, and policies. The American Economic Review, 84(2), pp. 261-265, 1994.

[27] Haltia, O. \& Keipi, K., Financiamiento de inversiones forestales en América Latina: El uso de incentivos, Banco Interamericano de Desarrollo, Environmental, Washington D.C., 1997.

[28] Comisión Nacional de Áreas Naturales Protegidas, (14 de 10 de 2014). Recuperado el 19 de 01 de 2016, de CONANP: http://www.conanp.gob.mx/regionales/

[29] Comisión Nacional de Áreas Naturales Protegidas, (17 de 10 de 2014). Recuperado el 19 de enero de 2016, de CONANP: http://www.conanp.gob.mx/acciones/\#

[30] Comisión Nacional Forestal, (26 de junio de 2015). Recuperado el 19 de 01 de 2016, de CONAFOR: http://www.conafor.gob.mx/web/apoyos/pronafor/ 